\title{
THE ATTITUDES AND EXPERIENCES OF THE INTERNET AND SOCIAL MEDIA USERS IN SERBIA
}

\author{
Slađana Đurić \\ Faculty of Economics in Subotica, University of Novi Sad, Republic of Serbia \\ dalisla@mts.rs
}

\begin{abstract}
The Internet and its platforms and services became very important tool for marketers in creating online advertising campaigns and for establishing and deepening relationship with their customers. Online marketing and creating opened, direct and transparent relationship with every individual customer is very powerful instrument in promotion of companies and significantly increases the chances of gaining competitive advantage. The purpose of this research paperwork was to get the knowledge about actual attitudes, opinions and experiences of Internet users in Serbia and to collect data that can be used for online campaigns planning. Various analysis were undertaken in order to present the potential of Internet and social media for marketers, companies and entrepreneurs in planning and implementing their online presence.
\end{abstract}

Key words: social networks, the Internet, the Internet users, social media, research, questionnaire, participants

\section{Introduction}

Constantly developing digital technologies, Internet and social networks have changed the way people connect and interact and transfered most of our communications from offline to online. Internet and social media became the main mean of communication between people and are also very powerfull tool for advertising campaigns and branding. Online media and platforms and its daily usage re-defined the „crowds“ phenomena, developed new language of communication (Đurić, 2018) and promoted new ocuppations such as youtuber, blogger, influencer etc. The interaction between people became passive
Original Scientific Paper doi:10.5937/jouproman7-22584 and is carried out through specific forms of communications and by using universal language (Đurić, 2018) of social networks (like, dislike, to google, tweet, troll, LOL, insta-friendly etc.). Social media and other digital platforms became very important source od various data about its users and their preferences and therefore they represent inevtable tool for predicting needs and wishes of very demanding and well informed customers. In order to achieve competive advantage, marketers must aproach their individual customers in time they are ready and opened to receive the information. „The use of the Internet empowers customers because they can go on the Web and quickly find out where to get the lowest prices for a particular product or service“" (Yannopoulos, 2011).

\section{Literature base}

Data represented in this paper are gathered as a part of a wider research undertaken by the author of this paper in 2018. The main motive of the research was to gather the insight into real attitudes and opinions of Internet users and their experiences with different Internet platforms and media. Experiences of Intenet users related to their online bying habits were also studied in that research. The research included 252 participants older than 18 years. 
The research was conducted following the overal concept of the research undertaken by Serbian Bureau of Statistics in April 2017, that analized the usage of Internet and e- commerce in Sebian households. The other research that was taken as the guide for author's research was the Master thesis from Wang and Abdullayeva presented in June 2011. These authors (Wang, Abdullayeva 2011) analyzed social commerce, e-commerce and social media as the field for customer relationship improvement, and developed the research model that was taken as the starting point for the research shown in this paperwork. Ghaith, Khaldoon and Anas (2014) discussed the Internet and its impact on channels of distibution in Jordan. They (Ghaith, Khaldoon, Anas 2014) also studied the Internet as an autonomous channel of distribution and its effect on the reduction of number of intermediaries in distribution channels. Their study was also taken as the ground for this research.

The Internet and its platforms and applications is constantly growing and developing and therefore marketers must use its full capacity to aproach new customers and to deepen their relationship with existing ones. Developing useful content and aproaching customers when and where they are ready and willing to accept the transmitted message is the imperativ for online promotion. Internet space became overcrowded and marketers are very close to cross over the edge of patience of online users with everlasting and constantly appearing commercials.

According to data published on Statista web-site (Statista, 2019) following social networks and platforms/applications were ranked to have the most active users per month: Facebook (2,320 Billion), Youtube (1,900 Billion), WhatsApp (1,600 Billion), Facebook Messenger (1,300 Billion), Instagram (1,000 Billion), Twitter
(330 Million), Linkedin (303 Million) etc. These statistics point out that there is wide range of possibilities and options for marketers to reach Billions of customers globally.

On the other hand, excessive and aggressive online advertising provoked the increase in add blocking application usage all over the world. The report from Deloitte (Deloitte, 2017) highlights that younger, employed, better educated audience with higher incomes are those who usually use add blocking applications. According to the same report (Deloitte, 2017), the laptop and desktop add blocking rate increased up to $30 \%$, which brings us to conclusion that over one quarter of paid adds will never reach potential buyers (Statista, 2019).

\section{Methodology}

This study was conducted to gain knowledge about the attitudes, opinions and experiences of Serbian citizens related to their usage of the Internet with the aim to show that the Internet, with its platforms, applications and social networks is a very powerfull tool for planning and creating online campaigns for products, services and events. Large amount of information posted by users on social networks and behavioral patterns of social media users can be used for reaching customers and for creating and maintaining profound and fertile relationship with them and for converting them into brand evangelists. Therefore it is of exeptional importance for companies to:

1) To develop product and services of high quality in order to attract desired audience

2) To conduct severe market and potential customers research and to plan online approach accordingly 
3) To create web site and social media presence that will attract targeted segments of customers and provoke them to undertake desired actions

4) To maintain relationship with customers through various activities that are suitable for segmented audience in terms of time and used platforms and aplications

5) To obtain resources, assets and highly skilled personnel for constant monitoring of all changes in customer's attitudes and online preferences.

This study was designed to show the exact rate of the Internet usage and its most popular platforms and contents among adult Serbian users, and it can be used as a guidance for companies and entrepreneurs to conduct random or selected customer segment research prior to udertaking activities related to online advertising. This study was undertaken to obtain qualitative and quantitative info about general attitudes of the Internet users, but adjusted and targeted questionnaires can be created in specific situations when market presence of a company or product/service is to be tested.

The questionnaire was designed in three parts. The first part was about demographic characteristics (the sex, age, education, employment, income per month), the second part included questions about the Internet usage and the third set of questions was related to the experience of the Internet users in e-commerce and their habits and buying paterns. This paperwork shows the results that were gained after analysing and processing data covered in the second part of the questionnaire. These questions were releted to the type of device users use to access the Internet (desktop computer, laptop computer, tablet, mobile phone), the purpose of the Internet usage (to gain information of interest, to access information on products/services, to look for a job, to communicate via e-mail, to participate in social networks etc.), the type of social network/platform they participate in, whether they follow advertisements or brands on social networks and whether they use the Internet to purchase products/services.

The questionnaire, containing 30 questions, was distributed to 252 participants $(20 \%$, was dispatched via Facebook, 30\% via e-mail and the rest $50 \%$ in paper) all older than 18 years of age, assuming that those respondents have some disposable monthly income (or some monetary amount disposable for purchasing products/services) and developed attitudes and habits related to the Internet usage. All participants in this study were Serbian citizens, with workplace and residence in Serbia and they participated in this study voluntary and anonymously. This questionnaire can be replicated, adjusted and used for some other research attempts. Questionnaire was created taking into account the willingness of participants and the time necessary to give honest answers and therefore questions were designed to enable straight answers (yes/no) or to pick applicable answer among several offered answers. It is very important to emphasize that no questionnaire was returned blank, the response rate was $100 \%$. The participants were chosen randomly among citizens of Belgrade, Novi sad, Sremska Mitrovica, Šid, Užice and are employees of JP "Vojvodinašume" Petrovaradin, JP "Vodovod" Sremska Mitrovica, Public Attorney's Office Sremska Mitrovica, The Serbian Business Registers Agency Belgrade, Karate Club "Sirmium" Sremska Mitrovica, Hairdressing salon "Milena" Šid, Gallery "Sava Šumanovič" Šid. The participants were also randomly chosen among several book and clothes stores shoppers and coffee shops and restaurants visitors. 
Table 1. General socio-demographic characteristics of study participants ( Total number: 252)

\begin{tabular}{|c|c|c|c|}
\hline \multicolumn{2}{|c|}{ General characteristic } & \multirow{2}{*}{$\begin{array}{c}\text { Number of participants } \\
\text { (n) }\end{array}$} & \multirow{2}{*}{$\begin{array}{c}\begin{array}{c}\text { Percentage } \\
(\%)\end{array} \\
57.94\end{array}$} \\
\hline Sex & Male & & \\
\hline & Female & 106 & 42.06 \\
\hline \multirow[t]{6}{*}{$\overline{\text { Age }}$} & $18-25$ & 27 & 10.71 \\
\hline & $26-35$ & 63 & 25.00 \\
\hline & $36-45$ & 70 & 27.78 \\
\hline & $46-55$ & 51 & 20.24 \\
\hline & $56-65$ & 29 & 11.51 \\
\hline & 66 and more & 12 & 4.76 \\
\hline \multirow[t]{6}{*}{ Education } & Less than 8 grades & 1 & .40 \\
\hline & Primary school & 16 & 6.35 \\
\hline & Secondary school & 110 & 43.65 \\
\hline & High school & 43 & 17.06 \\
\hline & Faculty & 72 & 28.57 \\
\hline & Postgraduate studies & 10 & 3.97 \\
\hline \multirow[t]{6}{*}{ Employment } & Student & 12 & 4.76 \\
\hline & Unemployed & 28 & 11.11 \\
\hline & In public sector & 124 & 49.21 \\
\hline & In private sector & 56 & 22.22 \\
\hline & Entrepreneur & 14 & 5.56 \\
\hline & Retired & 18 & 7.14 \\
\hline \multirow[t]{8}{*}{ Income } & Not stated & 3 & 1.19 \\
\hline & Less than 22000 dinars & 44 & 17.46 \\
\hline & $22001-35000$ dinars & 43 & 17.06 \\
\hline & $35001-45000$ dinars & 55 & 21.83 \\
\hline & $45001-55000$ dinars & 47 & 18.65 \\
\hline & $55001-65000$ dinars & 25 & 9.92 \\
\hline & $65001-75000$ dinars & 11 & 4.37 \\
\hline & 75001 and more & 24 & 9.52 \\
\hline
\end{tabular}

Source: Author's data

The results shown in this paper are processed using various methods of statistical analysis (MANOVA, ANOVA, Cronbach Alpha) in order to show corellation between the demographic criteria and the usage of the Internet and social media.

\section{The research results}

Following hypothesis were set prior to statistical processing of gained data:

H1: The age of participants is significantly related to the purpose of the Internet usage

$\mathrm{H} 2$ : The age of respondents define the type of the Internet platform/social media they use
H3: There is the interdependence between the age of respondents and whether they consult the Internet prior to making decision of purchasing product or service

H4: There is the interdependence between the age of respondents and whether they follow advertising campaigns on the Internet

H5: The education of participants is significantly related to the purpose of the Internet usage

Among total number of respondents (252), $239(94.84 \%)$ of them stated that they use the Internet. 
Table 2: MANOVA analysis of H1: The age of participants is significantly related to the purpose of the Internet usage

\begin{tabular}{lccc}
\hline Analysis & n & F & p \\
\hline MANOVA & 8 & 2.835 & .000
\end{tabular}

Based on $\mathrm{p}$ value set at $\mathrm{p}=.000$ (MANOVA) $\mathrm{H} 1$ can be accepted since all $\mathrm{p}>0$ (marked column values: $.014, .000, .000, .050,000, .002, .009, .009)$. These values prove that the age of participants affects the purpose of the Internet use.

\begin{tabular}{lllll}
\hline & $\chi$ & $\mathbf{R}$ & $\mathbf{F}$ & $\mathbf{p}$ \\
\hline $\begin{array}{l}\text { You use the Internet to access information of interest for You } \\
\text { (news, health, entertainment etc.) }\end{array}$ & .230 & .236 & 2.924 & .014 \\
$\begin{array}{l}\text { You use the Internet to access information about products/ } \\
\text { services }\end{array}$ & .303 & .318 & 5.563 & .000 \\
$\begin{array}{l}\text { You use the Internet to look for a job or for professional } \\
\text { training }\end{array}$ & .298 & .312 & 5.336 & .000 \\
$\begin{array}{l}\text { You use the Internet to communicate via e-mail } \\
\text { You use the Internet for activities in social networks } \\
\quad \text { (Facebook, Instagram etc.) }\end{array}$ & .204 & .209 & 2.248 & .050 \\
You use the Internet to purchase products/services online & .346 & .368 & 7.757 & .000 \\
$\begin{array}{l}\text { You use the Internet for Internet banking } \\
\text { You use the Internet to purchase holidays arrangements } \\
\text { and airplane tickets }\end{array}$ & .265 & .274 & 4.022 & .002 \\
\hline
\end{tabular}

\section{Source: Author's data}

For all values $\mathrm{p}<1$ it is evidently proved that the age of research participants are significant characteristic that determines the purpose of the Internet usage.

Further detailed analysis implicated that respondents of age 36-45 and 46-55 mainly use the Internet to access information important to them (news, health, entertainment etc.). Younger respondents of age 18-25 and 26-35 mainly use the Internet to participate in different social networks. Respondents of age 36-45 and 46-55 stated that they use the Internet to gain information on product and services and to communicate via e-mail. Participants of age 26-35 and 36-45 use the Internet to purchase online. 
Table 3: MANOVA analysis of $\mathrm{H2}, \mathrm{H3}, \mathrm{H} 4$ : There is significant distinction between: the age of respondents and: the type of the Internet platform/social media they use; the age of participants and whether they consult the Internet prior to making decision of purchasing product/service; the age of participants and whether they follow advertising campaigns on the Internet

\begin{tabular}{lccc}
\hline Analysis & n & F & p \\
\hline MANOVA & 9 & 3.936 & .000
\end{tabular}

Based on $\mathrm{p}$ value set at $\mathrm{p}=.000$ (MANOVA) $\mathrm{H} 2, \mathrm{H} 3, \mathrm{H} 4$ can be accepted since values $\mathrm{p}>0$ (marked column values: $.000, .000, .000, .085, .000, .000)$ prove that there is significant distinction between the age of participants and: the of the Internet platform/social media they use; if they consult the Internet prior to making decision of purchasing product/service; whether they follow advertising campaigns on the Internet.

\begin{tabular}{lllll} 
& $\boldsymbol{\chi}$ & $\mathbf{R}$ & $\mathbf{F}$ & $\mathbf{p}$ \\
\hline Which Internet platform/social media do you use? & & & & \\
Facebook & .311 & .328 & 5.937 & .000 \\
Instagram & .313 & .330 & 6.040 & .000 \\
YouTube & .270 & .281 & 4.227 & .000 \\
Pinterest & .116 & .116 & .679 & .642 \\
Linkedin & .163 & .165 & 1.387 & .229 \\
Twitter & .077 & .078 & .299 & .913 \\
Blogs & .191 & .195 & 1.954 & .085 \\
Do You consult the Internet prior to making decision on purchase & .541 & .601 & 27.969 & .000 \\
Do You follow advertising campaigns on the Internet? & & & & \\
\hline Source: Author data & .495 & .536 & 19.928 & .000 \\
\hline
\end{tabular}

Source: Author's data

The correlation between the age of participants and questions:

1. Which Internet platform/social media do You use (Facebook, Instagram, YouTube, Pinterest, Linkedin, Twitter, Blogs

2. Do You consult the Internet prior to making decision of purchasing product/services (to explore characteristics of the product, availability of the product, discounts, price comparison etc.)

3. Do You follow advertising campaigns on the Internet (adds for products/services on Facebook, Instagram, Youtube etc.)

is observed for all values $\mathrm{p}<1$ which proves $\mathrm{H} 2, \mathrm{H} 3$ and $\mathrm{H} 4$.

Further analysis explained that respondents of age 18-25 and 26-35 mainly use Facebook, Youtube and Instagram. Respondents of age 36-45 mainly stated that they follow blogs. Respondents of age 26- 35 and 36-45 in very high percentage (over 80\%) consult the Internet prior to making purchasing decision to explore product's characteristics, availability, prices etc and respondents of age 18-25 and 26-35 follow adds on the Internet. It is interesting to point out that respondents age 46-55 stated that they don't follow internet adds in percentage of $70.6 \%$. 
Table 4: MANOVA analysis of H5: The education of participants is significantly related to the purpose of the Internet usage

\begin{tabular}{lccc}
\hline Analysis & n & F & p \\
\hline MANOVA & 8 & 2.769 & .000 \\
\hline
\end{tabular}

Based on $\mathrm{p}$ value set at $\mathrm{p}=.000$ (MANOVA) H5 can be accepted for all values $\mathrm{p}<0.05$ (marked column values: $.000, .000, .020, .000,000, .000, .001)$. These values prove that the education of participants affects the purpose of the Internet use.

\begin{tabular}{|c|c|c|c|c|}
\hline & $\chi$ & $\mathbf{R}$ & $\mathbf{F}$ & $\mathbf{p}$ \\
\hline $\begin{array}{l}\text { You use the Internet to access information of interest for You } \\
\text { (news, health, entertainment etc.) }\end{array}$ & 3.703 & .741 & 6.083 & .000 \\
\hline $\begin{array}{l}\text { You use the Internet to access information about products/ } \\
\text { services }\end{array}$ & 9.71 & 1.941 & 9.185 & .000 \\
\hline $\begin{array}{l}\text { You use the Internet to look for a job or for professional } \\
\text { training }\end{array}$ & 2.22 & .445 & 2.72 & .020 \\
\hline You use the Internet to communicate via e-mail & 11.64 & 2.327 & 11.19 & .000 \\
\hline $\begin{array}{l}\text { You use the Internet for activities in social networks } \\
\text { (Facebook, Instagram etc.) }\end{array}$ & .81 & .163 & .65 & .661 \\
\hline You use the Internet to purchase products/services online & 6.01 & 1.203 & 5.209 & .000 \\
\hline You use the Internet for Internet banking & 7.32 & 1.465 & 7.564 & .000 \\
\hline $\begin{array}{l}\text { You use the Internet to purchase holidays arrangements } \\
\text { and airplane tickets }\end{array}$ & 3.67 & .733 & 4.139 & .001 \\
\hline
\end{tabular}

Source: Author's data

For all values $\mathrm{p}<0.05$ it is evidently proved that the education of research participants is a significant characteristic that determines the purpose of the Internet usage (H5).

Further detailed analysis implicated that respondents who have completed secondary school, high school and faculty use the Internet to access information of interest for them. Participants who completed secondary school and faculty access the Internet to gain information about products and services. Participants who completed faculty and postgraduates use the Internet to communicate via email. Respondents who have completed faculty purchase products/services online and those who have completed faculty and postgraduates use the Internet to purchase holiday arrangements and airplane tickets. It is interesting that all categories mainly responded negative to the usage of the Intenet for ebanking, and positive to participation in social networks. 
Table 5: Other significant statistics

\begin{tabular}{|c|c|c|c|}
\hline Question & Yes (in \%) & NO (in \%) & No answer \\
\hline You use the mobile phone to access the Internet & 77.78 & 22.22 & \\
\hline $\begin{array}{l}\text { You consult the Internet prior to purchase of product/ } \\
\text { service (exploring characteristics of products/ } \\
\text { services, availability of products/services, } \\
\text { discounts, comparison of prices etc.) }\end{array}$ & 75.00 & 22.62 & 2.38 \\
\hline $\begin{array}{l}\text { Are You a member of some brand fans community } \\
\text { (brand fan page on Facebook, Instagram etc) }\end{array}$ & 15.87 & 81.75 & 2.38 \\
\hline Do You use add block program/application & 28.17 & 67.86 & 3.97 \\
\hline $\begin{array}{l}\text { Are You annoyed by adds You receive via e-mail } \\
\text { or mobile phone }\end{array}$ & 47.62 & 49.60 & 2.78 \\
\hline Are You worried that information You provide when & & & \\
\hline $\begin{array}{l}\text { You fill out online ordering forms might be } \\
\text { misused }\end{array}$ & 55.16 & 42.06 & 2.78 \\
\hline Do You participate in online winning contests & 15.87 & 80.95 & 3.17 \\
\hline Do You trust online advertising campaigns & 18.65 & 78.57 & 2.78 \\
\hline $\begin{array}{l}\text { Do You read reviews form other users (posts, } \\
\text { comments, forums) about products/ } \\
\text { services You are planning to buy }\end{array}$ & 66.67 & 30.16 & 3.17 \\
\hline
\end{tabular}

Source: Author's data

The statistics presented in upper table show that participants in this research fit in global statistics regarding the use of mobile phones to access the Internet and usage of add blocking applications. Marked statistics also show that respondents mainly don't trust online adds and feel disturbed by them. Also, most of them consult the Internet prior to purchase of products and services, read reviews of other users of products and services they intent to buy, don't participate in online contests and feel worried about the safety of their personal data when buying online.

Table 6: Cronbach Alpha coefficient

$\begin{array}{lcc}\text { Domain } & \text { Number of items } & \text { Cronbach Alpha value } \\ \text { Internet and social networks usage } & 28 & 0.85 \\ \text { All questionnaire } & 72 & 0.854\end{array}$

Source: Author's data

The reliability test for the research constructs show that measures for all domains are reliable since the reliability of all the research is within values $0.83-0.88$.

Analysis indicated that the monthly income of respondents did not have any affect on their habit to consult the internet prior to making purchasing decisions nor it had any affect on them following advertisements on the Internet.

\section{Conclusion}

Internet in general and social media and platforms offer wide area of possibilities for marketers to conduct very successful and efficient online campaigns. The digits on social media users are stunning and well planned and organized approach to potential and existing customers may lead to very prosperous and deep manifestation of loyalty towards companies and brands in general. 
It is of crucial importance to approach customers only when they are ready and willing to receive and process the message from advertisers. Osterwalder (2002) pointed out that the trust and loyalty has became the crucial element of nowadays business that is characteristic for increasing virtual and reduced face-to-face contact. The increasing numbers of adblock users and ignoring online advertisements is a strong indicator of the fact that virtual space is violated and overcrowded by very aggressive advertising.

This research and similar studies are to be viewed as attempts to offer some info about the preferences of online users and some guidance in further researches of similar topics. Companies and entrepreneurs may conduct similar researches in order to obtain qualitative and quantitative data on real and actual opinions and preferences of their potential customers. Such studies may provide not only data about online behavior of Internet users but large users bases and focus groups may be used to conduct real-time researches and panel groups for investigation of opinion and attitudes towards companies and brands.

It is certain that this and similar researches point out huge potential and benefits of using Internet and social networks as the arena for wisely and carefully conducted online campaigns.

\section{References}

1) Deloitte (2017), Is there an \#Adlergic epidemic? Ad blocking across media, The Creative Studio at Deloitte, London, access June 2019 https://www2.deloitte.com/content/dam/D eloitte/global/Images/infographics/technol ogymediatelecommunications/gx-deloittetmt-2018-adblocking-media-report.pdf

2) Đurić S. (2018), Case study: Airbnb Social Media Campaign, Symorg 2018, Doing Business in the Digital Age:
Challenges, Aproaches and Solutions; Digital Trends in Marketing and Strategic Communications,

http://symorg.fon.bg.ac.rs/proceedings/20

18/papers/Digital\%20Trends\%20in\%20M arketing $\% 20$ and $\% 20$ Strategic $\% 20 \mathrm{Commu}$ nications.pdf

3) Ghaith M. A., Khaldoon H. K., Anas Y., H., (2014), Internet Usage and Traditional Distribution Channels: The Moderating Effect of the Firm's Size in Jordan, International Business Research, Vol. 7, No. 3, Canadian Center of Science and Education

4) Osterwalder A. (2002), An e/Business Model Ontology for Modeling e-Business, $15^{\text {th }}$ Bled Electronic Commerce Conference; e-Reality:Constructing the eEconomy, Bled, Slovenia, June 17-19, 2002

5) Republički Zavod za Statistiku (2017), Upotreba Informacionokomunikacionih Tehnologija u Republici Srbiji; Domaćinstva/Pojedinci, Preduzeća, ISSN 1820-9084, Republički Zavod za Statistiku, Beograd, access April 2018 http://publikacije.stat.gov.rs/G2017/Pdf/G 20176006.pdf

6) Statista, (2019), Most Famus Social Networks Sites Worldwide as of April 2019, Ranked by Number of active Users (In Millions), access June 2019 https://www.statista.com/statistics/272014 /global-social-networks-ranked-bynumber-of-users/

7) Statista, (2019), Ad Blocking Penetration Rate in Selected Countries Worldwide as of February 2018, access June 2019 https://www.statista.com/statistics/351862 /adblocking-usage/

8) Wang X, Abdullayeva G., (2011), The Realtionship Between Use of Social Media and Customer Relationship; From E/commerce Model Perspective, Master Thesis 15 HEC, INFM02 in informatics, School of Economics and Management, Lund University, Department of Informatics

9) Yannopoulos Dr. P. (2011), Impact of the Internet on Marketing Strategy Formulation, International Journal of Business and Social Science, Vol. 2, No. 18, October 2011 